\title{
Direct sequencing of the human microbiome readily reveals community differences
}

\author{
Justin Kuczynski', Elizabeth K Costello², Diana R Nemergut ${ }^{3}$, Jesse Zaneveld', Christian L Lauber', Dan Knights ${ }^{5}$, \\ Omry Koren ${ }^{6}$, Noah Fierer', Scott T Kelley ${ }^{7}$, Ruth E Ley ${ }^{6}$, Jeffrey I Gordon ${ }^{8}$ and Rob Knight ${ }^{9,10 *}$
}

\section{Abstract \\ Culture-independent studies of human microbiota by direct genomic sequencing reveal quite distinct differences among communities, indicating that improved sequencing capacity can be most wisely utilized to study more samples, rather than more sequences per sample.}

In the past few years, the availability of improved sequencing methods, including pyrosequencing [1], has revolutionized what we know about the microbes that inhabit our bodies. Although it has been known for decades that our microbial symbionts outnumber our own cells by about a factor of 10 [2], the differences in the repertoires of symbionts harbored by different healthy individuals, different sites within the individual, and by individuals over time are only now coming to light. Initially, it was assumed that a 'core microbiome' existed; that is, that a substantial number of microbial species was shared in each body habitat in all or most humans, and that the genomes of these core species could be used as scaffolds to assemble fragmentary data from short-read shotgun sequencing of microbial community DNA [3].

The first three individuals whose gut microbiomes were surveyed using substantial numbers of $16 \mathrm{~S}$ rRNA gene sequences shared few of their species, however [4]. Similarly, observations that a person's left and right hands have only $17 \%$ of bacterial species in common, and that two different people's hands share only 13\% [5], cast doubt on the concept of a substantial core set of microbial species shared by all or most people. This doubt has been reinforced by recent work that redefines core lineages or genes as 'core' even if shared by relatively few people

*Correspondence: rob.knight@colorado.edu

'Department of Chemistry and Biochemistry, University of Colorado, Boulder, CO 80309, USA

Full list of author information is available at the end of the article
[6,7]. In fact, on the basis of $16 \mathrm{~S}$ rRNA gene analyses we can rule out the possibility that, even within relatively homogeneous small populations of fewer than 100 individuals, everyone's skin-surface communities or gut communities share more than a tiny fraction of species [6-8]. This unanticipated variability in shared community membership, and also in other important aspects of the human microbiome, poses substantial conceptual and computational challenges.

Of particular importance for microbiome studies is the following question: what is the effect size? That is, using standard terminology from statistics, how distinguishable are two communities or groups of communities? Obtaining an answer is essential for addressing many practical concerns with experimental design. For example, the effect size determines how many individuals need to be recruited for a given study, and how many sequences need to be collected per sample to observe differences if they exist. These considerations are particularly important for the study of systemic disorders such as diabetes or some autoimmune disorders, which are expected to influence the microbiome in multiple body habitats. We need a sense of how much variation exists among different body habitats, how much variation is observed among healthy individuals for the same body habitat, and how much of a shift occurs due to a pathophysiologic state. It is also important to define the most appropriate method for determining the magnitude of similarity or difference between communities, as the choice of method has a large influence on the results of community comparisons [9-12]. A general discussion of the pros and cons of different metrics of community overlap is beyond the scope of this paper (see [9-12] for reviews). Here, we summarize the types and sizes of effects found in studies that used various methods of comparing groups of samples, and look for large-scale patterns that can give information on the number of individuals and sequences that are needed to observe different types of effects (Figure 1).

A variety of interrelated features differentiate microbial communities. These features include the the relative abundance of specific taxa (the proportion of the bacteria 
(a)

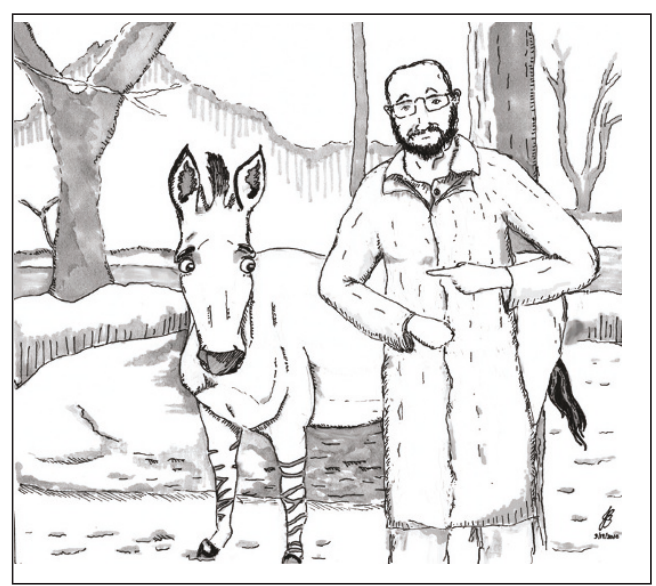

(b)

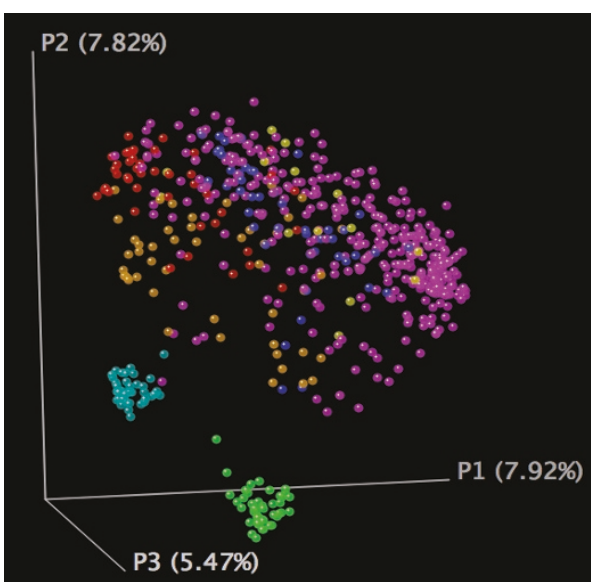

(c)

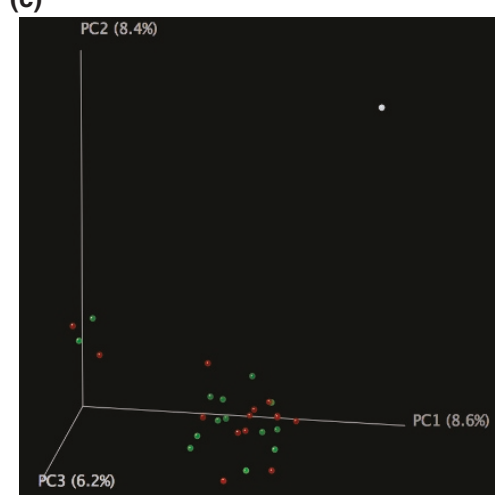

100

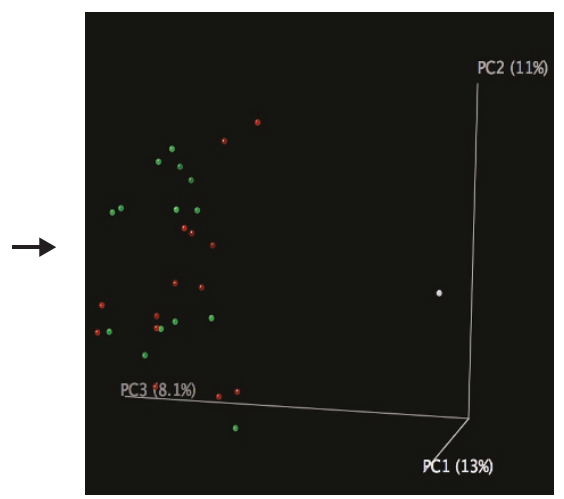

10

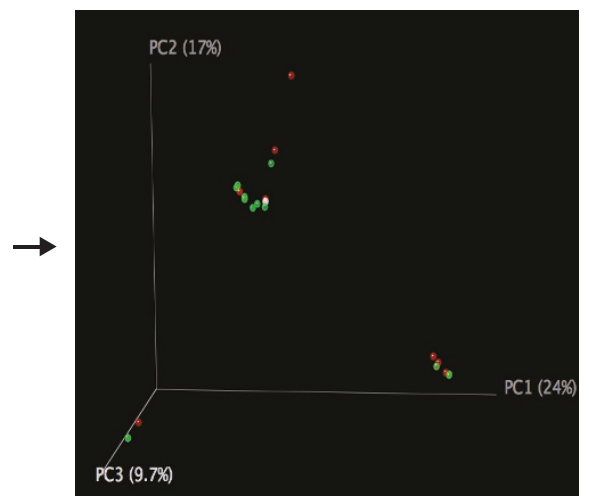

1

Figure 1. The problem of distinguishing between sequences. (a) An investigator contemplating the problem of distinguishing between sequences from the gut of Equus asinus and the volar forearm of humans. (b) Our solution; guess the effect size based on the effect sizes reported in published studies; perform simulations based on these effect sizes as shown in Figure 2, and then acquire sufficient sequences to resolve microbial community differences of the expected magnitude. (c) When comparing the Equus asinus gut (white point) to human forearms (red and green points represent left and right arms, respectively), 100 or even 10 sequences per sample provide sufficient resolution, but one sequence per sample does not.provide sufficient resolution, but one sequence per sample does not.

in the sample that are Firmicutes, for example), the level of species richness or diversity observed within a community (alpha diversity), and the degree to which different communities share membership or structure (beta diversity). A major challenge in comparing studies is that there is no consistent way in which the size of community differences is reported, as the type of difference that is relevant depends on the study. For example, lean and obese mice and humans differ in their ratios of prominent bacterial phyla (Bacteroidetes (which include the common gut commensal Bacteroides), Firmicutes (Gram-positive bacteria, including Lactobacillus and Clostridium), and Actinobacteria (which include Corynebacteria and Mycobacteria) [13-15]); men's and women's hands differ in the number of species-level phylotypes (defined as organisms with $16 \mathrm{~S}$ sequence identity $>97 \%$ ) observed on average [5]; and samples from the same or similar sites on the bodies of different individuals cluster together using UniFrac-based principal coordinates analysis $[4,16,17]$. UniFrac is a metric for comparing microbial communities using phylogenetic information, which has been implemented in several tools.

Because of the diverse ways in which microbial communities respond to various environmental factors, it is difficult to compare effect sizes across different studies or systems, as an analysis that highlights differences in one system may obscure them in another. Thus, in what follows, we review effect types and sizes as reported by the authors of individual studies. We focus on variation in human-associated microbial community 
diversity as assessed by $16 \mathrm{~S}$ rRNA gene sequence surveys of abundant lineages, using various measures of both within- and between-sample diversity (alpha and beta diversity, respectively). We review comparisons of microbial communities in relationship to both sampling depth (that is, number of sequences per sample) and breadth (that is, number of samples or individuals). We then perform simulations using an atlas of microbes associated with different sites in the human body to ask how many sequences per sample are needed in order to detect differences across individuals, time, and locations within the body.

\section{Reported effect sizes between and within different body habitats}

Table 1a provides an illustrative (though not exhaustive) overview of the literature regarding differences observed in different body habitats and locations in healthy individuals, and the number of subjects and sequences that were used to identify these differences. Although metagenomic studies that examine all the genes in the genome are also of immense interest, shotgun metagenomic data are so far available only from the gut and for a relatively few samples, and so the range of questions that can be addressed at present is substantially more limited than for $16 \mathrm{~S}$ rRNA-based surveys, the type of survey we consider here. One robust finding that exemplifies relative effect sizes is that there appears to be a greater degree of variation in microbial community composition between individuals than within the same individual over time (Table 1a). This has been found to be true in multiple studies and over a wide range of body habitats. For example, gut community composition is relatively stable in the same individual across a period of months when diet is consistent $[6,16]$, and even to a certain degree when diet is altered. (Changes in the Firmicutes:Bacteroidetes ratio have been reported in individuals who lost weight, whether they were consuming low-calorie fat- or carbohydrate-restricted diets, but despite these shifts in relative abundance, interpersonal variation was the largest effect observed using phylogenetic comparisons of the communities [14].) Likewise, skin community composition is more similar within a subject than between subjects over a period of months $[16,18]$, as are oral, nasal and external auditory canal communities [16]. These results indicate that you are likely to be more similar to yourself in 3 months time than to your friend today in terms of the bacteria you harbor.

\section{Microbial community changes in human disease and environmental samples}

Although a wide range of studies in healthy subjects have identified substantial interpersonal variation in overall microbial community composition, how do these effect sizes compare with differences correlated with disease, or in response to treatments of various environmental samples? To address this question, we reviewed cultureindependent, $16 \mathrm{~S}$ rRNA gene-based surveys associated with different physiological conditions (Table 1b) and associated with experimental manipulations in nonhuman environments (which were surprisingly scarce; Table 1c).

One of the best-characterized effects of health status on the gut microbiome is the association between obesity and the proportional representation of Bacteroidetes, Firmicutes and Actinobacteria [6,13-15]. Studies in mice indicate that the microbiota contributes to the obese state by providing the host with a greater amount of energy from the diet compared with the microbiota of a lean host [15], as well as by manipulating host genes that regulate the deposition of energy in adipocytes [19]. The obesity-associated microbiomes of humans (and mice) are enriched in functional genes for certain types of carbohydrate metabolism, and this is directly attributable to the reduction in the numbers of genomes of members of the Bacteroidetes $[6,15]$.

However, even the size of the differences in gut bacterial community composition of obese versus lean hosts is debated, as different studies using different methodologies have returned varied results [20]. The impact of methodology is particularly evident in a study of twins concordant for obesity or leanness, in which the observed relative abundances of Bacteroidetes, Actinobacteria and Firmicutes, as judged by sequencing of different regions of $16 \mathrm{~S}$ rRNA clones, depended on the sequencing approach - pyrosequencing of PCR products, Sanger sequencing of $16 \mathrm{~S}$ rRNA clones, or shotgun sequencing and phylogenetic classification of reads [6]. However, the direction of the effect was consistent across methodologies, and detectable with as few as a couple of hundred sequences per sample.

Observable phenotypes such as obesity may be caused by a variety of underlying factors, and which of those factors is responsible for shifts in the host's microbiota is difficult to address in such correlative studies. Experimental manipulations of microbial communities, however, allow determination of the relative effects of specific variables on overall community composition or the abundance of particular taxa, and as such, allow researchers to draw conclusions regarding cause and effect. Examples of experimental manipulations of non-human environments that used 16S rRNA gene sequencing approaches (either clone libraries or pyrosequencing) and that were well enough replicated to allow statistical analysis are shown in Table 1c. For soil samples, three to four replicates with 70 to 100 sequences were sufficient to observe differences in microbial communities due to land use and moisture regimes $[21,22]$. For piglet gut microbiota, the effects of 
Table 1. Variations observed among different types of microbial communities, and the extent of sequencing and sampling used

\begin{tabular}{|c|c|c|c|c|}
\hline Topic & $\begin{array}{c}\text { Number } \\
\text { of } \\
\text { subjects }\end{array}$ & 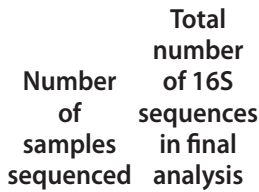 & $\begin{array}{c}\text { Average } \\
\text { number of } \\
\text { sequences } \\
\text { per } \\
\text { sample }\end{array}$ & Study conclusions \\
\hline
\end{tabular}

(a) Microbial communities associated with healthy humans

Oral $\quad 120 \quad 120 \quad 14,115 \quad 118$

(saliva)

18

Collected saliva from 10 individuals at each of 12 globally widespread locations. They attributed approximately $13.5 \%$ of the total variation in the distribution of genera to differences between individuals and found little evidence for geographic structure: $11.7 \%$ of the variation was among individuals from the same location while just $1.8 \%$ was among individuals from different locations

$\begin{array}{llll}\text { Oral } & 3 & 29 & 298,261\end{array}$

buccal mucosa, palate)

Skin
(right and left
volar forearm)
volar forearm)

Skin

(right and

left palms)
51

102

351,630

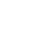

\begin{abstract}
Skin
(20 skin sites, including moist dry, and sebaceous sites)
\end{abstract}

10

300

112,283

$\begin{array}{ccccc}\text { Gut } & 3 & 18 & 11,831 & 657 \\ \text { Gut } & 154 & 281 & 1,947,381 & 6,930\end{array}$

(b) Microbial communities and human disease

$\begin{array}{lll}\text { Obesity } & 12 \text { subjects } & 50 \quad 18,348 \\ & 2 \text { controls } & \end{array}$

$\begin{array}{lccc}\text { Diabetes } & \begin{array}{l}\text { 10 Diabetic patients } \\ \text { 10 healthy subjects* }\end{array} & 382,229 \\ & & 357,782 \\ & & \\ & & \\ \text { Crohn's } & \text { 6 CD patients } & 16 & 1,590 \\ \text { disease } & 5 \text { UC patients } & 678 \\ \text { (CD) and } & 5 \text { healthy subjects } & 1,037 \\ \text { ulcerative } & & \\ \text { colitis (UC) } & & \end{array}$

Collected samples from various oral niches of three individuals; $26 \%$ of the unique sequences and $47 \%$ of species-level phylotypes found in the study were found in all three subjects. Bacterial community composition was shaped primarily by oral niche: principal components analysis differentiated communities from shedding (tongue, cheek, palate) versus tooth surfaces Sampled the superficial left and right volar forearms of six healthy subjects (four of whom were sampled again 8 to 10 months later). Samples from the same subject at the same time point (left versus right) were not significantly different, whereas samples from the same subject at different time points could be significantly different

Collected skin swabs from the left and right palms of 51 volunteers. On average, individuals shared only $17 \%$ of species-level phylotypes between their right and left palms, while only $13 \%$ of species-level phylotypes were shared between different individuals. (UniFrac similarity between hands from different individuals $=0.30$, and the same individual $=0.36$ to 0.38.) Palm surface bacterial community structure was determined by handedness, time since washing, and the individual's sex

Obtained samples from 20 skin sites on each of 10 individuals (half of whom were sampled twice). They found that interpersonal variation in community membership and structure depended on skin site, and that subjects were more similar to themselves (site-to-site) than to others. Four of the five re-sampled subjects were also more similar to themselves over time than they were to other volunteers. Bacterial community composition was shaped by microhabitat: sebaceous, moist, or dry Interpersonal and site-to-site variation in three subjects at six sites. Between subject dissimilarity was greater than within subject dissimilarity Interpersonal variation was found to be largest between unrelated individuals, smaller between children and their mothers, still smaller between twins, and dramatically smaller in the same individual over time. (Average UniFrac distance over time within-individual $=0.69$ and between unrelated individuals $=0.80$ )

Obese people have fewer Bacteroidetes (5\%; $P<0.001)$ and more Firmicutes $(85 \% ; P=0.002)$ than lean controls (25\% Bacteroidetes and $75 \%$ Firmicutes). During the diet, the relative abundance of Bacteroidetes increased from 5 to $20 \%$ $(P<0.001)$ and the abundance of Firmicutes decreased from 85 to $75 \%(P=0.002)$. Increased abundance of Bacteroidetes correlated with percentage loss of body weight ( $R^{2}=0.8$ for the CARB-R diet and 0.5 for the FAT-R diet, $\left.P<0.05\right)$, and not with changes in dietary calorie content over time $\left(R^{2}=0.06\right.$ for the CARB-R diet and 0.09 for the FAT-R diet)

37,001 The proportion of Firmicutes was significantly higher $(P=0.03)$ in the controls (mean 56.4\%) compared to the diabetic group (mean 36.8\%). Accordingly, phyla Bacteroidetes and Proteobacteria were somewhat but not significantly enriched in the diabetic group (50.4 and $4.1 \%$ in the diabetic group compared with 35.1 and $2.7 \%$ in the healthy group, respectively)

207 Proteobacteria were significantly $(P=0.0007)$ increased in CD patients (13\%) versus UC patients $(9.4 \%)$ or healthy subjects $(8.5 \%)$. Bacteroidetes were far less diverse than Firmicutes, containing only 32 phylotypes, versus 87 specieslevel phylotypes in the latter phylum, but were nevertheless the most abundant, representing over $70 \%$ of total clones. Bacteroidetes were significantly increased (75\%) in CD patients versus UC patients (64.3\%) or healthy subjects (67.4\%) The increase in Bacteroidetes and Proteobacteria was accompanied by a significant $(P=0.0001)$ decrease in Firmicutes (CD,10\%; UC, 25.8\%; healthy subjects, 24\%), all belonging to the class Clostridia in the CD group 
Table 1. Continued

\begin{tabular}{|c|c|c|c|c|c|c|}
\hline Topic & $\begin{array}{l}\text { Number } \\
\text { of } \\
\text { subjects }\end{array}$ & $\begin{array}{l}\text { Number } \\
\text { of } \\
\text { samples } \\
\text { sequenced }\end{array}$ & $\begin{array}{l}\text { Total } \\
\text { number } \\
\text { of } 16 \mathrm{~S} \\
\text { sequences } \\
\text { in final } \\
\text { analysis }\end{array}$ & $\begin{array}{l}\text { Average } \\
\text { number of } \\
\text { sequences } \\
\text { per } \\
\text { sample }\end{array}$ & Study conclusions & Reference \\
\hline $\begin{array}{l}\text { CD and } \\
\text { UC }\end{array}$ & $\begin{array}{c}20 \text { CD patients } \\
15 \text { UC patients } \\
14 \text { healthy subjects }\end{array}$ & 49 & $\begin{array}{l}809 \\
691 \\
235\end{array}$ & 35 & $\begin{array}{l}\text { The results obtained from CD and healthy subject samples did not differ } \\
(P>0.05) \text {. Bacterial numbers associated with non-inflamed and inflamed } \\
\text { mucosa within CD and UC groups did not differ ( } P>0.05 \text { ). The ratio of } \\
\text { Actinobacteria:Bacteroidetes:Firmicutes: Proteobacteria differed between } \\
\text { healthy (approximately 1:27:53:6\%), UC (approximately 0.3:34:48:7\%) and CD } \\
\text { subjects (approximately 0.5:34:40.5:6\%) }\end{array}$ & [43] \\
\hline $\begin{array}{l}\text { CD and } \\
\text { UC }\end{array}$ & $\begin{array}{l}190 \text { CD, UC or } \\
\text { healthy patients } \\
\text { (around equal } \\
\text { numbers) }\end{array}$ & 190 & 15,172 & 80 & $\begin{array}{l}\text { Bacteroidetes }(10 \%, P=0.001) \text { and Firmicutes }(20 \%, P=0.001) \text { were greatly } \\
\text { depleted while Actinobacteria }(10 \%, P=0.001) \text { and Proteobacteria }(50 \%, \\
P=0.001) \text { were substantially more abundant in the inflammatory bowel } \\
\text { disease (IBD) subset samples, relative to control subset samples (approximately } \\
20 \% \text { Bacteroidetes, approximately } 50 \% \text { Firmicutes, approximately } \\
5 \% \text { Actinobacteria, approximately } 10 \% \text { Proteobacteria) }\end{array}$ & [44] \\
\hline $\begin{array}{l}\text { Necrotizing } \\
\text { enterocolitis } \\
\text { (NEC) }\end{array}$ & $\begin{array}{c}10 \text { infants } \\
\text { with NEC and } \\
10 \text { healthy infants }\end{array}$ & 21 & 5,354 & 255 & $\begin{array}{l}\text { For the control infants four phyla were present: Proteobacteria, (34.97\% relative } \\
\text { abundance), Firmicutes ( } 57.79 \%) \text {, Bacteroidetes ( } 2.45 \%) \text { and Fusobacteria (0.54\%) } \\
\text { with } 4.25 \% \text { unclassified bacteria. However, NEC patients had only two phyla, } \\
\text { Proteobacteria ( } 90.72 \%) \text { and Firmicutes }(9.12 \%) \text { with } 0.16 \% \text { unclassified bacteria. } \\
\text { The average proportion of Proteobacteria was significantly increased and the } \\
\text { average proportion of Firmicutes was significantly decreased compared to } \\
\text { controls ( } P=0.001 \text { ) }\end{array}$ & [45] \\
\hline $\begin{array}{l}\text { Clostridium } \\
\text { difficile- } \\
\text { associated } \\
\text { diarrhea } \\
\text { (CDAD) }\end{array}$ & $\begin{array}{l}4 \text { ICD patients } \\
3 \text { RCD patients } \\
3 \text { healthy subjects }\end{array}$ & 10 & $\begin{array}{l}581 \\
447 \\
399\end{array}$ & 143 & $\begin{array}{l}\text { Using rarefaction curves, species richness in the patients with ICD (initial } \\
\text { episode of antibiotic-associated diarrhea due to C. difficile) was similar to that } \\
\text { in the control subjects, with the shape of the curve revealing that the total } \\
\text { richness of the microbial community had not been completely sampled } \\
\text { (minimum of } 20 \text { phylotypes). However, the species richness in the patients } \\
\text { with RCD (recurrent antibiotic associated diarrhea due to C. difficile) was } \\
\text { consistently lower (around ten phylotypes) than both that in the patients with } \\
\text { ICD and that in the control subjects }\end{array}$ & [46] \\
\hline $\begin{array}{l}\text { Gastric } \\
\text { cancer }\end{array}$ & $\begin{array}{c}10 \text { non-cardia } \\
\text { gastric cancer patients } \\
5 \text { control patients }\end{array}$ & nts & 140 & 9 & $\begin{array}{l}\text { No significant differences in microbial compositions were found between } \\
\text { cancer patients and controls }\end{array}$ & [47] \\
\hline $\begin{array}{l}\text { Helicobacter } \\
\text { pylori } \\
\text { colonization }\end{array}$ & $\begin{array}{l}19 \text { H.pylori }(+) \\
\text { subjects } \\
4 \text { H.pylori }(-) \\
\text { subjects }\end{array}$ & 23 & 1,833 & 80 & $\begin{array}{l}\text { Subjects negative for } \mathrm{H} \text {. pylori had twice as many Fusobacteria as } \mathrm{H} \text {. pylori- } \\
\text { positive subjects ( } 10 \% \text { compared to } 5 \% \text {, respectively). Twenty percent of the } \\
\text { clone libraries derived from } \mathrm{H} \text {. pylori-positive patients were non-H. pylori } \\
\text { Proteobacteria compared with } 10 \% \text { in the control subjects; this was also the } \\
\text { case for Bacteroidetes ( } 20 \% \text { compared with } 10 \% \text { in the control) }\end{array}$ & [48] \\
\hline
\end{tabular}

(c) Experimentally manipulated microbial communities

\begin{tabular}{|c|c|c|c|c|c|c|}
\hline $\begin{array}{l}\text { Restoration } \\
\text { of wetland } \\
\text { soils } \\
\qquad 3\end{array}$ & $\begin{array}{l}3 \text { agriculture } \\
\text { wetlands, } \\
3 \text { restored } \\
\text { wetlands and } \\
3 \text { reference wetlands }\end{array}$ & 13 & 1,235 & 95 & $\begin{array}{l}\text { A significant difference in the Proteobacteria:Acidobacteria ratio from around } \\
0.6 \text { to around } 0.4 \text { was observed between agricultural and reference wetlands, } \\
\text { respectively }(P<0.001) \text {. A difference was also found in the relative abundance } \\
\text { of } \beta \text {-Proteobacteria from } 14 \text { to } 3 \% \text { in the same soils }(P<0.001)\end{array}$ & {$[22]$} \\
\hline $\begin{array}{l}\text { Soil } \\
\text { moisture }\end{array}$ & $\begin{array}{l}4 \text { wet and } \\
4 \text { dry soils }\end{array}$ & 8 & 665 & 83 & $\begin{array}{l}\text { The relative abundance of Proteobacteria decreased from } 48 \text { to } 36 \% \text { in wet } \\
\text { versus dry plots }(P<0.05) \text {. Acidobacteria increased in relative abundance from } \\
7 \text { to } 23 \% \text { in the same soils }(P<0.01)\end{array}$ & {$[21]$} \\
\hline $\begin{array}{l}\text { Antibiotic } \\
\text { effects on } \\
\text { piglet gut } \\
\text { microbiota }\end{array}$ & $\begin{array}{l}6 \text { control pigs } \\
\text { and } 6 \text { pigs } \\
\text { treated with } \\
\text { chlor-tetracycline }\end{array}$ & 12 & 1,900 & 171 & $\begin{array}{l}\text { An effect of antibiotics was seen on the overall community composition } \\
(P<0.03)\end{array}$ & [23] \\
\hline $\begin{array}{l}\text { Effects of a } \\
\text { 24-hour fast } \\
\text { on mouse gut } \\
\text { microbiota }\end{array}$ & $\begin{array}{l}4 \text { to } 5 \text { fasted } \\
\text { and control mice }\end{array}$ & 38 & 145,428 & 3,827 & $\begin{array}{l}\text { The fast resulted in a significant increase in the proportion of Bacteroidetes } \\
\text { (approximately } 21 \text { to approximately } 42 \%, P=0.01 \text { ) and a significant decrease } \\
\text { in the fraction of Firmicutes (approximately } 77 \text { to around } 53 \%, P=0.007 \text { ) within } \\
\text { the gut microbial community }\end{array}$ & [49] \\
\hline $\begin{array}{l}\text { Effects of diet } \\
\text { and } \\
\text { genotype on } \\
\text { murine gut } \\
\text { microbiota }\end{array}$ & $\begin{array}{l}5 \text { individuals } \\
\text { from } 2 \text { genotypes } \\
\text { fed standard } \\
\text { or low-fat chow }\end{array}$ & 20 & 25,790 & 1,290 & $\begin{array}{l}\text { The relative abundance of Bacteroidetes decreased (around 90\% versus } \\
\text { around } 40 \% \text { ) in animals fed the high-fat diet regardless of genotype }(P<0.001) \text {. } \\
\text { Likewise, mice fed the standard chow diet showed a lower relative abundance of } \\
\text { Firmicutes (around } 7 \text { versus around 42) independent of genotype }(P<0.001)\end{array}$ & [50] \\
\hline $\begin{array}{l}\text { Antibiotic } \\
\text { effects on } \\
\text { canine gut } \\
\text { microbiota }\end{array}$ & $\begin{array}{l}5 \text { dogs } \\
\text { sampled } \\
\text { three times }\end{array}$ & 15 & 44,096 & 2,940 & $\begin{array}{l}\text { Enterococcus-like organisms, Pasteurella species, and Dietzia species all } \\
\text { increased significantly }(P<0.05) \text { following tylosin treatment }\end{array}$ & [51] \\
\hline
\end{tabular}




\section{Box 1: How many sequences does it take...?}

Costello et al. [16] found that variation in membership of bacterial communities was primarily explained by body habitat, secondarily by host individual (within habitats), and finally by time (within habitats and individuals). Specifically, variation in species composition measured using the unweighted UniFrac metric was 1.19 times larger between habitats than within habitats. Within habitats, interpersonal variation was 1.15 times larger than variation within individuals over time. Within habitats and individuals, variation over 3 months was 1.06 times larger than variation over 24 hours. Thus, the smallest effect size observed showed that samples collected 24 hours apart were significantly more similar to each other than to those collected 3 months apart.

The influence of sequencing depth on the ability to recapture these differences can be conveniently tested by simulating the effects of sampling fewer sequences and then performing comparisons of bacterial community membership using the unweighted UniFrac metric [26]. The UniFrac metric measures the difference between two communities in terms of the amount of evolutionary history that is unique to either of the two: for a pair of communities, the sum of the lengths of the branches on a phylogenetic tree that leads only to members of one community divided by the sum of the lengths of the branches that lead to members of either community yields the UniFrac distance between the communities [26]. Using the QIIME (Quantitative Insights Into Microbial Ecology) software package, we randomly drew sequences from samples at various depths below the original study's 1,315 \pm 420 (standard deviation) sequences per sample, then calculated UniFrac distance between all pairs of samples. Using only ten sequences per sample, the main results of the original study were recovered: variation between samples was most prominent for samples from different body habitats; and for the same body habitat, samples originating from different individuals varied more than samples originating from the same indivdual over time. The original study [16] also found that among samples from the same body habitat on the same individual, samples varied more when separated by 3 months than when separated by only 24 hours; our reanalysis using only 10 sequences per sample only suggested this result (Figure 2a,b).

These same UniFrac distances can be used with the program PRIMER v6 [27] to assess the partitioning of the variability in distances in multivariate space using nested models and PERMANOVA [28], a technique that uses label permutations to estimate the distribution of their test statistics under the null hypothesis that within-group distances are not significantly different from between-group distances. In this analysis, PERMANOVA uses the UniFrac distances to compute a test statistic similar to an F-ratio, and then reports both the significance of the statistic and the portion of variation explained by each nested level of factor. Figure 2c shows the portion of variation explained in PERMANOVA in response to sequencing depth when run with the default settings using the nested experimental design Month(Person(Habitat)), featuring Habitat as the highest hierarchical level. Remarkably, this analysis shows that a relatively low sequencing depth is sufficient to allow us to partition variability in bacterial community membership among the various factors in our experimental design, and to rank correctly the relative importance of these factors. For example, the observation that bacterial community composition varied less over 24 hours than over 3 months became significant when 50 or more sequences per sample were obtained (PERMANOVA Monte Carlo $P<0.001$ ). These results are consistent with previous work from several groups showing that broad-scale trends in microbial community analysis can be recaptured with samples consisting of only a few dozen sequences [29-32].

Related techniques can be used to address the potential of using a deeply sequenced reference dataset to classify sparsely sequenced microbial samples. This approach is likely to be increasingly relevant as sequence-based microbial ecology studies grow both in number and in extent, and as reference databases become more extensive and user friendly. In this analysis, each narrowly defined body site from Costello et al. [16] (for example, volar forearm, forehead, and so on) is compared with each other site. For each pair of sites, one sample was selected: how many sequences from that sample were required to identify which of the two body sites it came from? A given depth of sequencing ('Seqs for 95\% cluster accuracy' in Figure 2d) was considered sufficient for discrimination when it placed the test sample closer to samples from the same body site than to samples from the other body sites under consideration more than $95 \%$ of the time. As expected, correct discrimination in this manner requires deeper sequencing when the differences between body sites are more subtle. For example, body sites within the broader skin habitat, such as palm and knee, often required well over 100 sequences for discrimination, whereas dissimilar habitats such as the oral cavity and hair rarely required more than 100 sequences for discrimination.

The effect sizes in this type of analysis can be quantified using an adaptation of the population-genetics statistic known as the 'fixation index', or $F_{\text {ST }} F_{\text {ST }}$ was originally used to detect genetically based population subdivision (also known as genetic differentiation) among populations of animals or plants within a species [33], but can easily be adapted to measure the degree of differentiation between clusters (or categories) of microbial communities [12]. Values of $F_{S T}$ typically range from 0 to 1, where 0 indicates no differentiation and 1 indicates complete differentiation. Hudson et al. [34], following Slatkin [35], provide a simple definition of $\mathrm{F}_{\text {ST }}$ that is easily adapted to microbial community distance metrics such as Unifrac distances: $F_{S T}=\left(P_{\text {Between }}-P_{\text {Within }}\right) / P_{\text {Between, }}$ where $P_{\text {Between }}$ and $P_{\text {Within }}$ represent the average Unifrac distances between and within samples, respectively, from two categories. The $F_{S T}$ is reported as the abscissa in Figure $2 d$. For many pairs of body habitats, surprisingly few sequences (often fewer than ten) are required to classify a new habitat, although with smaller effect sizes more sequences are frequently required. It is important to note that, as with any assessment of beta diversity, these patterns are due to differences in the most abundant species in each sample; the effects of the rare biosphere [36] will inherently be lost as sampling depth decreases. However, the importance of rare species (that is, alpha diversity) in human body habitats generally has yet to be shown. If rare species do turn out to correlate better with physiological states than does overall community composition, deeper sequencing will be required. However, overall patterns can be recovered with surprisingly few reads, and a focus on the common species that make up most of the biomass has been useful in many other ecosystems as well. 


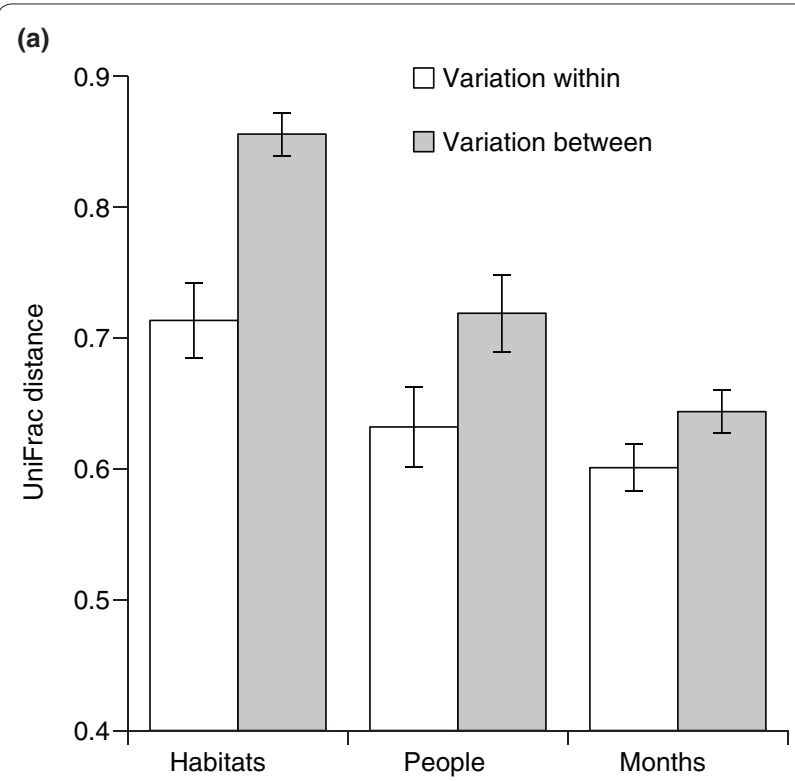

(b)
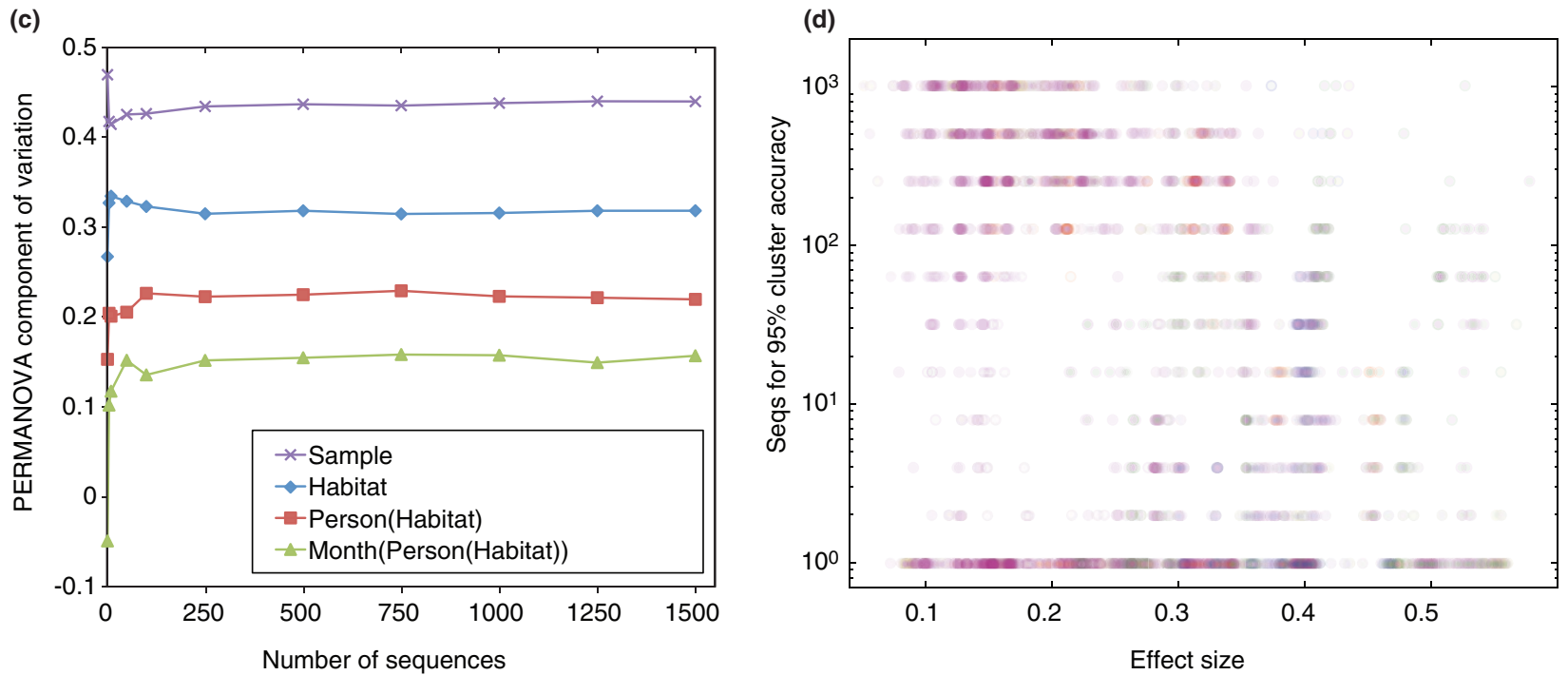

Figure 2. Variation in human body habitats within and between people. (a) The full dataset (approximately 1,500 sequences per sample); (b) the dataset sampled at only 10 sequences per sample, showing the same pattern; (c) the relationship between sequencing depth and the PERMANOVA component of variation. The amount of variation explained by the factors plateaus at relatively shallow sequencing depths. Note that the proportion of variation captured by differences between the samples (that is, residual variation) is still highest despite the explanatory values of the three factors examined. (d) Effect size determines the number of sequences required for sample identification. Each point in the figure represents a specific sample selected from a pair of body sites, and the number of sequences required to correctly distinguish which site the sample originated from. The point is colored according to the two body sites under consideration, the center's color represents the broad category the selected sample originated from, the border color represents the other broad category under consideration. Many body sites share the same broad category, and thus some points have the same border and center coloring. Red, external ear canal; yellow, hair; green, oral cavity; blue, gut; magenta, skin; gray, nostril. ns, not significant.

antibiotics on overall community composition were evident with as few as 96 sequences per sample [23]. It would be fascinating to test whether similar antibiotic-induced effects in outbred populations of humans with diverse diets [24] can be found with relatively few sequences. Similarly, it would be important to consider sampling depth under human physiological conditions in cases where the effect size is known to be large, for example, in the development of the infant gut microbiota [25].

\section{Has the depth of sequencing used up to now really been necessary?}

The literature reviewed in Table 1 reports how many sequences were used to reveal a variety of different 
effects. Could the same results have been achieved with less sequencing? To begin to address this question, we carried out a limited reanalysis of a study of multiple body habitats by Costello et al. [16], which encompasses variability explained by nested factors with different effect sizes (Box 1).

In conclusion, the results described here, and previously reported [8,37], show that arbitrarily choosing to generate large numbers of sequences may not be the most cost-effective way to identify changes in microbial communities associated with different physiological or pathophysiological states. Instead, we call for a few standardized methods to assess differences among microbial communities, which will allow for effect size and power calculations, and therefore a considered assessment of the number of individuals and sequences required to differentiate among given communities. The following four methods have been successful in a range of studies: differences in alpha diversity (number of phylotypes observed or extrapolated); differences in abundance of specific lineages; differences in location on a principal coordinates plot obtained from UniFrac distances or other metrics; and the $F_{S T}$ measure described in the previous section.

The rapid increase in sequencing capacity provides a spectacular opportunity to advance the field in ways that were unimaginable even 3 years ago. How can individual investigators, or groups of investigators, use these resources most wisely at this unique moment of democratization of the ability to perform sequencebased studies? The data summarized here suggest that study designs consisting of tens of thousands of samples sequenced at shallow coverage will be highly informative (depending on the effect size), and such studies are possible with the instruments available today. Given recent observations that inter-habitat and interpersonal variations are large effects, we believe that individual researchers can and should sieze the opportunity provided by these findings to analyze vast numbers of samples at low-coverage (for example, 100 to 1,000 sequences). At this number of samples, detailed exploration of spatial and temporal dynamics of microbial communities will be possible, as will comparisons of large patient populations. In addition, replicate samples can be acquired and analyzed without too strongly impairing the breadth of an investigation, allowing more robust experimental designs to be implemented. One can envisage that perhaps within the next few years, a group of motivated high-school students might, for a science-fair project, be able to track movements in microbes between humans and their pets and livestock across the planet. These studies, especially when combined with hypothesis-driven approches to understanding the effects of factors such as diet and antibiotic exposure, could go far beyond even the largest purely observational studies being contemplated today.

Such studies will yield an overall map of variation within the human microbial ecosystem, and relate differences to specific physiological states within and between individuals in a manner that is replicated across individuals. These studies will serve as a framework to identify and compare the shifts that take place in the microbial community that are related to specific disorders.

\section{Acknowledgements}

We thank the Crohn's and Colitis Foundation of America, the Bill and Melinda Gates Foundation, the $\mathrm{HHMI}$ and the $\mathrm{NIH}$ for support of work by the authors cited in this review.

\section{Author details}

'Department of Molecular, Cellular and Developmental Biology, ${ }^{3}$ Institute of Arctic and Alpine Research (INSTAAR), ${ }^{4}$ Cooperative Institute for Research in Environmental Sciences (CIRES), ${ }^{5}$ Department of Computer Science,

${ }^{9}$ Department of Chemistry and Biochemistry, University of Colorado, Boulder, CO 80309, USA. ${ }^{2}$ Department of Microbiology and Immunology, Stanford University, Stanford, CA 94305, USA. 'Department of Microbiology, Cornell University, Ithaca, NY 14853, USA. Department of Biology, San Diego State University, San Diego, CA 92182, USA. ${ }^{8}$ Center for Genome Sciences, Washington University School of Medicine, St Louis, MO 63108, USA. ${ }^{10} \mathrm{Howard}$ Hughes Medical Institute, University of Colorado, Boulder, CO 80309, USA

Published: 5 May 2010

\section{References}

1. Margulies M, Egholm M, Altman WE, Attiya S, Bader JS, Bemben LA, Berka J, Braverman MS, Chen YJ, Chen Z, Dewell SB, Du L, Fierro JM, Gomes XV, Godwin BC, He W, Helgesen S, Ho CH, Irzyk GP, Jando SC, Alenquer ML, Jarvie TP, Jirage KB, Kim JB, Knight JR, Lanza JR, Leamon JH, Lefkowitz SM, Lei M, Li J, et al: Genome sequencing in microfabricated high-density picolitre reactors. Nature 2005, 437:376-380.

2. Van Houte J, Gibbons RJ: Studies of the cultivable flora of normal human feces. Antonie Van Leeuwenhoek 1966, 32:212-222.

3. Turnbaugh PJ, Ley RE, Hamady M, Fraser-Liggett CM, Knight R, Gordon Jl: The human microbiome project. Nature 2007, 449:804-810.

4. Eckburg PB, Bik EM, Bernstein CN, Purdom E, Dethlefsen L, Sargent M, Gill SR, Nelson KE, Relman DA: Diversity of the human intestinal microbial flora. Science 2005, 308:1635-1638.

5. Fierer N, Hamady M, Lauber CL, Knight R: The influence of sex, handedness, and washing on the diversity of hand surface bacteria. Proc Natl Acad SCi USA 2008, 105:17994-17999.

6. Turnbaugh PJ, Hamady M, Yatsunenko T, Cantarel BL, Duncan A, Ley RE, Sogin ML, Jones WJ, Roe BA, Affourtit JP, Egholm M, Henrissat B, Heath AC, Knight R, Gordon JI: A core gut microbiome in obese and lean twins. Nature 2009, 457:480-484.

7. Qin J, Li R, Raes J, Arumugam M, Burgdorf KS, Manichanh C, Nielsen T, Pons N, Levenez F, Yamada T, Mende DR, Li J, Xu J, Li S, Li D, Cao J, Wang B, Liang H, Zheng H, Xie Y, Tap J, Lepage P, Bertalan M, Batto JM, Hansen T, Le Paslier D, Linneberg A, Nielsen HB, Pelletier E, Renault P, et al: A human gut microbial gene catalogue established by metagenomic sequencing. Nature, 464:59-65.

8. Hamady M, Knight R: Microbial community profiling for human microbiome projects: Tools, techniques, and challenges. Genome Res 2009, 19:1141-1152.

9. Legendre P, Gallagher ED: Ecologically meaningful transformations for ordinations of species data. Oecologia 2001, 129:271-280.

10. Lozupone CA, Knight R: Species divergence and the measurement of microbial diversity. FEMS Microbiol Rev 2008, 32:557-578.

11. Magurran AE: Measuring Biological Diversity. Oxford: Blackwell; 2004.

12. Martin AP: Phylogenetic approaches for describing and comparing the diversity of microbial communities. App/ Environ Microbio/ 2002, 68:3673-3682. 
13. Ley RE, Backhed F, Turnbaugh P, Lozupone CA, Knight RD, Gordon Jl: Obesity alters gut microbial ecology. Proc Natl Acad Sci USA 2005, 102:11070-11075.

14. Ley RE, Turnbaugh PJ, Klein S, Gordon Jl: Microbial ecology: human gut microbes associated with obesity. Nature 2006, 444:1022-1023.

15. Turnbaugh PJ, Ley RE, Mahowald MA, Magrini V, Mardis ER, Gordon J: An obesity-associated gut microbiome with increased capacity for energy harvest. Nature 2006, 444:1027-1031.

16. Costello EK, Lauber CL, Hamady M, Fierer N, Gordon Jl, Knight R: Bacterial Community variation in human body habitats across space and time. Science 2009, 326:1694-1697.

17. Fierer N, Lauber CL, Zhou N, McDonald D, Costello EK, Knight R: Forensic identification using skin bacterial communities. Proc Natl Acad Sci USA 2010, 107:6477-6481.

18. Grice EA, Kong HH, Conlan S, Deming CB, Davis J, Young AC; NISC Comparative Sequencing Program, Bouffard GG, Blakesley RW, Murray PR, Green ED, Turner ML, Segre JA.: Topographical and temporal diversity of the human skin microbiome. Science 2009, 324:1190-1192.

19. Backhed F, Ding H, Wang T, Hooper LV, Koh GY, Nagy A, Semenkovich CF, Gordon Jl: The gut microbiota as an environmental factor that regulates fat storage. Proc Natl Acad Sci USA 2004, 101:15718-15723.

20. Ley RE: Obesity and the human microbiome. Curr Opin Gastroenterol, 26:5-11

21. Castro HF, Classen AT, Austin EE, Norby RJ, Schadt CW: Soil microbial community responses to multiple experimental climate change drivers. Appl Environ Microbiol 2010, 76:999-1007.

22. Hartman WH, Richardson CJ, Vilgalys R, Bruland GL: Environmental and anthropogenic controls over bacterial communities in wetland soils. Proc Natl Acad Sci USA 2008, 105:17842-17847

23. Rettedal E, Vilain S, Lindblom S, Lehnert K, Scofield C, George S, Clay S, Kaushik RS, Rosa AJ, Francis D, Brözel VS: Alteration of the ileal microbiota of weanling piglets by the growth-promoting antibiotic chlortetracycline. Appl Environ Microbiol 2009, 75:5489-5495.

24. Dethlefsen L, Huse S, Sogin ML, Relman DA: The pervasive effects of an antibiotic on the human gut microbiota, as revealed by deep 16S rRNA sequencing. PLOS Bio/ 2008, 6:e280.

25. Palmer C, Bik EM, Digiulio DB, Relman DA, Brown PO: Development of the human infant intestinal microbiota. PLoS Biol 2007, 5:e177.

26. Lozupone C, Knight R: UniFrac: a new phylogenetic method for comparing microbial communities. Appl Environ Microbiol 2005, 71:8228-8235.

27. Clarke KR, Gorley RN: Primer v6 [http://www.primer-e.com/]

28. Anderson MJ: Distance-based tests for homogeneity of multivariate dispersions. Biometrics 2006, 62:245-253.

29. Lozupone CA, Knight R: Global patterns in bacterial diversity. Proc Nat/ Acad Sci USA 2007, 104:11436-11440.

30. Ley RE, Lozupone CA, Hamady M, Knight R, Gordon J: Worlds within worlds: evolution of the vertebrate gut microbiota. Nat Rev Microbiol 2008, 6:776-788.

31. Tamames J, Abellan JJ, Pignatelli M, Camacho A, Moya A: Environmental distribution of prokaryotic taxa. BMC Microbiol 2010, 10:85

32. Auguet JC, Barberan A, Casamayor EO: Global ecological patterns in uncultured Archaea. ISME J 2010, 4:182-190.

33. Holsinger KE, Weir BS: Genetics in geographically structured populations: defining, estimating and interpreting F(ST). Nat Rev Genet 2009, 10:639-650.

34. Hudson RR, Slatkin M, Maddison WP: Estimation of levels of gene flow from DNA sequence data. Genetics 1992, 132:583-589.

35. Slatkin M: Inbreeding coefficients and coalescence times. Genet Res 1991, 58:167-175.

36. Sogin ML, Morrison HG, Huber JA, Mark Welch D, Huse SM, Neal PR, Arrieta
JM, Herndl GJ: Microbial diversity in the deep sea and the underexplored 'rare biosphere'. Proc Natl Acad Sci USA 2006, 103:12115-12120.

37. Ley RE, Hamady M, Lozupone C, Turnbaugh PJ, Ramey RR, Bircher JS, Schlege ML, Tucker TA, Schrenzel MD, Knight R, Gordon Jl: Evolution of mammals and their gut microbes. Science 2008, 320:1647-1651.

38. Nasidze I, Li J, Quinque D, Tang K, Stoneking M: Global diversity in the human salivary microbiome. Genome Res 2009, 19:636-643.

39. Zaura E, Keijser BJ, Huse SM, Crielaard W: Defining the healthy 'core microbiome' of oral microbial communities. BMC Microbio/ 2009, 9:259.

40. Gao Z, Tseng CH, Pei Z, Blaser MJ: Molecular analysis of human forearm superficial skin bacterial biota. Proc Natl Acad Sci USA 2007, 104:2927-2932.

41 Larsen N, Vogensen FK, van den Berg FW, Nielsen DS, Andreasen AS, Pedersen BK, AI-Soud WA, Sorensen SJ, Hansen LH, Jakobsen M: Gut microbiota in human adults with type 2 diabetes differs from non-diabetic adults. PLoS One, 5:e9085.

42. Gophna U, Sommerfeld K, Gophna S, Doolittle WF, Veldhuyzen van Zanten SJ: Differences between tissue-associated intestinal microfloras of patients with Crohn's disease and ulcerative colitis. J Clin Microbio/ 2006 , 44:4136-4141

43. Bibiloni R, Mangold M, Madsen KL, Fedorak RN, Tannock GW: The bacteriology of biopsies differs between newly diagnosed, untreated, Crohn's disease and ulcerative colitis patients. J Med Microbiol 2006 55:1141-1149.

44. Frank DN, St Amand AL, Feldman RA, Boedeker EC, Harpaz N, Pace NR: Molecular-phylogenetic characterization of microbial community imbalances in human inflammatory bowel diseases. Proc Natl Acad Sci USA 2007, 104:13780-13785.

45. Wang Y, Hoenig JD, Malin KJ, Qamar S, Petrof EO, Sun J, Antonopoulos DA Chang EB, Claud EC: 16S rRNA gene-based analysis of fecal microbiota from preterm infants with and without necrotizing enterocolitis. ISME J 2009, 3:944-954.

46. Chang JY, Antonopoulos DA, Kalra A, Tonelli A, Khalife WT, Schmidt TM, Young VB: Decreased diversity of the fecal microbiome in recurrent Clostridium difficile-associated diarrhea. J Infect Dis 2008, 197:435-438.

47. Dicksved J, Lindberg M, Rosenquist M, Enroth H, Jansson JK, Engstrand L: Molecular characterization of the stomach microbiota in patients with gastric cancer and in controls. J Med Microbio/ 2009, 58:509-516.

48. Bik EM, Eckburg PB, Gill SR, Nelson KE, Purdom EA, Francois F, Perez-Perez G, Blaser MJ, Relman DA: Molecular analysis of the bacterial microbiota in the human stomach. Proc Natl Acad Sci USA 2006, 103:732-737.

49. Crawford PA, Crowley JR, Sambandam N, Muegge BD, Costello EK, Hamady M, Knight R, Gordon Jl: Regulation of myocardial ketone body metabolism by the gut microbiota during nutrient deprivation. Proc Natl Acad Sci USA 2009, 106:11276-11281.

50. Hildebrandt MA, Hoffmann C, Sherrill-Mix SA, Keilbaugh SA, Hamady M, Chen YY, Knight R, Ahima RS, Bushman F, Wu GD: High-fat diet determines the composition of the murine gut microbiome independently of obesity. Gastroenterology 2009, 137:1716-1724.

51. Suchodolski JS, Dowd SE, Westermarck E, Steiner JM, Wolcott RD, Spillmann T, Harmoinen JA: The effect of the macrolide antibiotic tylosin on microbial diversity in the canine small intestine as demonstrated by massive parallel 16S rRNA gene sequencing. BMC Microbio/ 2009, 9:210.

\section{doi:10.1186/gb-2010-11-5-210}

Cite this article as: Kuczynski J, et al.: Direct sequencing of the human microbiome readily reveals community differences. Genome Biology 2010 $11: 210$. 